\title{
Characterization of the Glycosyltransferase Activity of DesVII: Analysis of and Implications for the Biosynthesis of Macrolide Antibiotics
}

\author{
Svetlana A. Borisova, Lishan Zhao, Charles E. Melançon III, Chai-Lin Kao, and \\ Hung-wen Liu* \\ Division of Medicinal Chemistry, College of Pharmacy, and Department of Chemistry and \\ Biochemistry, University of Texas, Austin, TX 78712
}

Preparation of TDP-D-desosamine (1), 10-deoxymethynolide (2), and YC-17 (4)

The sugar substrate $\mathbf{1}$ was obtained by hydrolysis of erythromycin to release desosamine followed by chemical conversion to its TDP form according to a published precedure (Chen, H.; Yamase, H.; Murakami, K.; Chang, C.-w.; Zhao, L.; Zhao, Z.; Liu, H.-w. Biochemistry 2002, 41, 9165-9183).

The macrolactone substrate $\mathbf{2}$ was purified from the fermentation broth of $S$. venezuelae KdesI-80 mutant, whose desosamine biosynthetic genes had been partially disrupted (Borisova, S. A.; Zhao, L.; Sherman, D. H.; Liu, H.-w. Org. Lett. 1999, 1, 133-136).

Preparation of YC-17 (4) involved the construction of a $S$. venezuelae mutant in which the $\mathrm{P} 450$ gene responsible for the hydroxylation of $\mathrm{YC}-17$, pikC, was replaced with kanamycin resistance marker [(a) Graziani, E. I.; Cane, D. E.; Betlach, M. C.; Kealey, J. T.; McDaniel, R. Bioorg. Med. Chem. Lett. 1998, 8, 3117-3120. (b) Betlach, M. C.; Kealey, J. T.; Ashley, G. W.; McDaniel, R. Biochemistry 1998, 37, 14937-14942. (c) Xue, Y.; Wilson, D.; Zhao, L.; Liu, H.-w.; Sherman, D. H. Chem. Biol. 1998, 5, 661-667.]. The major product produced by this mutant strain, KpikC, was isolated and its ${ }^{1} \mathrm{H}$ NMR spectral data were in agreement with previously reported [(a) Kinumaki, A.; Suzuki, M. J. Chem. Soc. Chem. Commun. 1972, 744-745. (b) Cane, D. E.; Graziani, E. I. J. Am. Chem. Soc. 1998, 120, 2682-2683.].

\section{DesVII Activity Assay}

A typical assay mixture contained $50 \mathrm{mM}$ Tris $\bullet \mathrm{HCl}\left(\mathrm{pH} 7,8\right.$, or 9), $6 \mathrm{mM} \mathrm{MgCl}_{2}$, $1 \mathrm{mg} / \mathrm{mL}$ BSA, $1 \mathrm{mM} 2(50 \mathrm{mM}$ stock in ethanol), $1.2 \mathrm{mM} \mathrm{1,} 21 \mu \mathrm{M}$ DesVII, and approximately 5-10 $\mu \mathrm{M}$ DesVIII (stocks in 10\% glycerol). The reaction was incubated at $29^{\circ} \mathrm{C}$ for $2-30 \mathrm{~h}$. The assay solution was then extracted with equal volume of chloroform, and the composition of the chloroform layer was analyzed by TLC (as described in Ref. 9). The $\mathrm{R}_{\mathrm{f}}$ values were approximately 0.4 and 0.6 for $\mathrm{YC}-17$ (4) and 2, respectively. Alternatively, the reaction mixture was filtered through Microcon YM-10 to remove proteins and the filtrate was analyzed by HPLC. An Alltech Econosil C18 column was used $(4.5 \times 250 \mathrm{~mm}, 5 \mu \mathrm{m})$ and elution was performed isocratically with $50 \%$ acetonitrile in $57 \mathrm{mM}$ ammonium acetate. The flow rate was $1 \mathrm{~mL} / \mathrm{min}$ and detector was set at $235 \mathrm{~nm}$. The retention time for $\mathbf{2}$ was $6.4 \mathrm{~min}$ and that for the product $\mathbf{4}$ (as a broad peak) fluctuated between 17.5 and 19.0 min, depending on its concentration.

\section{Enzymatic Preparation of YC-17}

To confirm the identity of DesVII product, a large scale reaction was ran as above with $18 \mu \mathrm{mol}$ of $\mathbf{2}, 27 \mu \mathrm{mol}$ of $\mathbf{1}, 0.4 \mu \mathrm{mol}$ DesVII, and approximately $0.1-0.2 \mu \mathrm{mol}$ DesVIII in a total volume $10 \mathrm{~mL}$ of $50 \mathrm{mM}$ Tris $\bullet \mathrm{HCl}$ buffer (pH 9) for $19 \mathrm{~h}$. Products were extracted with chloroform and analyzed by HPLC, MS, and NMR. 